\title{
Dokumenty osobiste jako transdyscyplinarne wyzwanie dla kategorii świata przeżywanego — wprowadzenie
}

\author{
DOI: 10.19195/2083-7763.7.1
}

Artykuły zaprezentowane w niniejszym tomie dotyczą teoretycznych i analitycznych doświadczeń badawczych przedstawicieli różnych dyscyplin naukowych, w których dokumenty osobiste traktuje się jako świadectwa działających struktur wartości kulturowych, językowych, politycznych i innych. Tym samym pytamy o możliwość wypracowania kategorii badawczych, które mogą być charakterystyczne $\mathrm{w}$ obszarze transdyscyplinarnym ${ }^{1}$. Nie chodzi jednak o to, aby przedstawiciele każdej z dyscyplin $\mathrm{z}$ osobna działali wbrew zasadom wypracowanym w każdej z nich, lecz by ich celem było znalezienie tego, co łączy różne dziedziny albo przynajmniej wspólne wskazanie kierunku dalszych poszukiwań. Identyfikowanie lub konstruowanie takich właśnie kategorii jest procesem najeżonym trudnościami. Wydaje się jednak, że trudność często leży nie po stronie przedmiotu badań, lecz po stronie charakteru badanych pojęć i kategorii, strategii użytych do ich analiz, a także przyzwyczajeń samych badaczy, np. niemożności zmiany przez nich „starych nawyków”, niechęci do zmiany założeń lub „otwarcia” się na inne metody badawcze ${ }^{2}$. Tymczasem wystawienie się bez zasłon i zabezpieczeń na bezpośrednią konfrontację z tym, co dla nich inne i obce oraz w konsekwencji pozwolenie sobie na bycie zdumionym i zaskoczonym ${ }^{3}$ otwiera szerokie możliwości interakcyjnego uwspólnienia stanowisk: „Porozumienie w rozmowie zakłada, że partnerzy są już do niego gotowi i starają się uznać to, co im obce

1 Ten problem z różnym nasileniem pojawia m.in. w następujących publikacjach: „Przegląd Socjologiczny” 64, 2015, nr 4; R. Czekalska, „Pisz mi o wszystkim dokładnie...” - rzeczywistości kulturowe w listach malarzy z kregu Bombay Progressive Artists' Group, „Societas/Communitas” 2015, nr 1-2 (19-20), s. 237-254; Rzeczywistość i zapis: problemy badania tekstów w naukach społecznych i humanistycznych, red. W. Doliński et al., Łódź 2016; W. Doliński, Zapisy autobiograficzne - od doświadczenia do map interpretatorów, „Przegląd Socjologii Jakościowej” 13, 2017, nr 3 (w druku).

2 Por. F. Znaniecki, Metoda socjologii, przeł. E. Hałas, Warszawa 2007, s. 278; Metoda biograficzna w socjologii, red. K. Kaźmierska, Kraków 2012, s. 25.

3 P. Dybel, Granice rozumienia i interpretacji. O hermeneutyce Hansa-Georga Gadamera, Kraków 2004, s. 414. 
i przeciwstawne. Gdy dokonuje się to po obu stronach i każdy z partnerów, wierny swym racjom, rozważa też racje przeciwne, można w końcu przez niedostrzegalny, ale też niedowolny przekład punktów widzenia [...] dojść do ustalenia wspólnego języka i wspólnej konkluzji”" . Warto podejmować wysiłek transgresji w teorii i stosowanych metodach badań, ponieważ nawet brak zgodnych konkluzji otwiera nowe, często nierozpoznane kierunki dociekań badawczych, tym bardziej że, jak zobaczymy na przykład w tekstach Marcina Stabrowskiego lub Jerzego Żurki, cechy pisanych dokumentów osobistych umożliwiają zbliżenie stanowisk w kwestii rozumienia wspólnie używanych pojęć oraz w sposobie rozwiązywania zagadnień metodologicznych.

Różnice w statusie metodologicznym między treścią zarejestrowanego w nagraniu tekstu rozmowy lub wywiadu (spisanie) a tym co dzieje się „pomiędzy” autorem a przyjmowaną przez niego pisemną formą opisu doświadczeń (zapisanie) ${ }^{5}$ zmuszają do sformułowania pytania o możliwość i sposób dotarcia do intencji autora. Bezsprzecznie jego intencja poprzedza decyzję o pisemnym utrwalaniu takiego, a nie innego doświadczenia. Na ile więc powinniśmy starać się dotrzeć do sfery decyzji, a na ile wystarczy ograniczyć się do tego, co zostało utrwalone. Istotne jest to, $\mathrm{w}$ jakim zakresie i jakimi metodami przedstawiciele różnych dyscyplin koncentrują się na jednej lub drugiej sferze bądź na obydwóch. Istotnym obszarem intencji jest pytanie o wybór konkretnej formy tego utrwalenia (np. w liście, wpisie w dzienniku, pamiętniku, eseju, dialogu, wierszu i w innych formach). Odpowiedź na nie także może wyglądać inaczej w różnych dziedzinach badawczych. Niemniej, po pierwsze, nośnik ma znacznie, a po drugie ma on związek z intencjami autora i jako taki podlega różnorakim interpretacjom, co traktowane łącznie zdecydowanie zachęca do ponownego przemyślenia kategorii świata przeżywanego.

Różnica między tekstem mówionym a pisanym jako podstawa empiryczna jest dobrze widoczna w sporze między P. Ricoeurem a H.G. Gadamerem, dla którego podstawą poznania świata była rozmowa, a nie pismo będące oznaką odrywania się podmiotów poznających od możliwości poznawczych. Ricoeur z kolei celowo wprowadził pojęcie tekstu (przez co rozumiał tekst pisany), gdyż to tekst wprowadzał dopiero trwałe znaczenia, a nie tylko negocjacje znaczeń, próby ich ustalania w trakcie rozmowy. Dla Gadamera tekst spisany jest zubożeniem rozmowy, natomiast tekst zapisany dzięki aktowi zapisu staje się już sam w sobie elementem świata kultury. W ten sposób odrywa się od intencjonalności twórcy i daje możliwość jego rozpatrywania poznawczego właśnie jako element kultury ${ }^{6}$. Co więcej, tekst zapi-

${ }^{4}$ H.G. Gadamer, Prawda i metoda. Zarys hermeneutyki filozoficznej, przeł. B. Braun, Warszawa 2004, s. 523.

${ }^{5}$ Wskazywaliśmy na tę ideę w innym miejscu, por. W. Doliński, J. Żurko, Wybrane problemy statusu poznawczego tekstów pisanych - wprowadzenie, [w:] Rzeczywistość i zapis..., s. 7-21.

${ }^{6}$ Stąd Łotmanowski „tekst kultury” istnieje jako mechanizm stawania się kultury, a jednocześnie jest rezultatem tego stawania się — „system modelujący”. 
sany może być aktualizowany ciągle na nowo w nowych kontekstach kulturowych i „obarczany” intencjami innymi niż autorskie. Proces „zapominania” o autorskich intencjach tekstu pisanego jest chyba historyczną koniecznością. Jak pisał Ricoeur: „W tym tkwi największa doniosłość pisma: doprowadza ono do wyzwolenia rzeczy napisanej, treści, od takich warunków dyskursu, jakie ustanawia rozmowa"7. Dzięki temu „wyzwoleniu” możliwe jest radykalne poszerzenie możliwości poznawczych, gdyż tekst pisany daje się ciągle poddawać na przemian procesom interpretacji i rozumienia. A poza tym przedstawia pewną wizję świata przeżyć, i to niekoniecznie samego autora tekstu, lecz właśnie jego odbiorcy. Odbiorca tekstu odkrywa w nim swój własny świat, a tekst tym samym staje się „pośrednikiem w rozumieniu nas samych przez nas samych"

Wskazane kwestie mogą sugerować odmienne pytania od tych, na których koncentrują się badacze (auto)biografii wykorzystujący różne formy wywiadu naukowego, dziennikarskiego, "potocznego" lub badacze retoryki narracji i analizy dyskursu w jego różnych odmianach. W życiu codziennym obecnych jest coraz więcej form wypowiedzi pisemnych, które, posługując się terminologią klasyka semiologii - Jurija Łotmana, można określić jako „teksty kultury” czy też „wtórne”, „prymarne systemy modelujące” ${ }^{10}$. Przybierając różne formy i wygląd, „teksty” trafiają do nas za pośrednictwem wielu nośników. Rozwój technologii komputerowych wprowadza nowe konteksty społeczne, domagające się wnikliwej analizy i obserwacji. Dynamiczny rozwój mediów elektronicznych rodzi niebezpieczeństwo, że wytwarzane w ich obrębie „teksty kultury” będą traktowane przede wszystkim jako dane statystyczne, co odwróci uwagę od ich związku z kwestią świata przeżywanego oraz z najważniejszą w tym wypadku kwestią relacji materii nośnika, treści przekazu i intencji (odbiorcy i nadawcy).

Zaprezentowane teksty, odnosząc się do badań jakościowych, wyraźnie korespondują z nurtem humanistycznym w socjologii. W badaniach tego rodzaju adaptacja metod i technik $\mathrm{z}$ różnych dziedzin nauki jest nie tylko często stosowana, lecz ze względu na charakter przedmiotu badań (np. sfera wartości) jest właściwie koniecznością. Sądzimy, że refleksja nad sferą wartości może połączyć kilka dziedzin badawczych. Uprzednio jednak należy zredefiniować ograniczenia własnej dyscypliny i uznać możliwości otwarcia się na stosowanie kategorii charakterystycznych dla innych dyscyplin, na co wskazywaliśmy już wcześniej. Być może okaże się, że to co ulokowane na marginesach kilku dziedzin w połączeniu i we wspólnej pracy badawczej stanowi dość obszerne terytorium eksploracji badawczej. Biorąc pod uwagę rozumienie niektórych elementów dokumentu osobistego i ściśle z nim związanego świata przeżywanego, praca nad „wspólnym

7 P. Ricoeur, Język, tekst, interpretacja, przeł. P. Graff, K. Rosner, Warszawa 1989, s. 237.

8 B. Baszczak, Paula Ricoeura hermeneutyka tekstu, „Fenomenologia” 2007, nr 5, s. 140.

${ }^{9}$ D. Ziemiańska-Sapija, Semiotyka szkoły tartuskiej jako nauka o kulturze, Warszawa 1987, s. $21-36$.

10 B. Żyłko, Semiotyka kultury. Szkoła tartusko-moskiewska, Gdańsk 2009, s. 109-148. 
językiem" jest możliwa w takich dyscyplinach, jak filozofia, kulturoznawstwo, antropologia kulturowa, literaturoznawstwo, historia, językoznawstwo, semiologia, psychologia. W nich bowiem podobieństwa procedur metodologicznych i obszarów metateoretycznych są istotne z praktycznego, poznawczego punktu widzenia, o czym przekonują się badacze funkcjonujący w zespołach związanych choćby $\mathrm{z}$ niektórymi wymiarami pracy socjalnej ${ }^{11}$. W tej perspektywie istotne byłoby ponowne przemyślenie kategorii świata przeżywanego. Wieloraka krytyka, której została poddana, nie powinna hamować takiego przedsięwzięcia. Przeciwnie, mogłaby wzbogacić współczesne jej ujęcie i rozumienie. Husserlowskie założenie o świecie przeżywanym jako świecie par excellance personalnym oraz o humanistyce jako nauce o ludzkiej subiektywności w jej świadomościowym odniesieniu do świata jawiącego się i dostarczającego jej motywacji do działania i doznawania może być dla współczesnych badaczy dokumentu osobistego nie tylko interesujące poznawczo, lecz także stanowić fundamenty metodologii.

Podejście transdyscyplinarne jest nieodzowne, albowiem doświadczenia badawcze przedstawicieli wielu dyscyplin naukowych oferują komplementarne wobec rozwiązań socjologicznych sposoby analizy i interpretacji pisanych rzeczywistości kulturowych. Ważny jest charakter badań prowadzonych m.in. przez literaturoznawców, np. nad pamiętnikami z XVII wieku, lub historyków opisujących zasady konstrukcji faktu czy zdarzenia historycznego. Część z tych obszarów badawczych została zaprezentowana w poniższych artykułach. Na przykład pojawiające się w tekstach kwestie literatury i literackości skłaniają do namysłu nad pytaniem, czy i jak te kategorie mogą być sensownie badane poza literaturoznawstwem? Jeśli zgodnie $\mathrm{z}$ tradycją formalistyczną (Roman Jakobson, Jurij N. Tynianow i inni) będziemy rozumieli literackość jako sztukę słowa tworzoną po to, by realizować przede wszystkim funkcję poetycką (a w mniejszym stopniu inne funkcje, np. ekspresywną, perswazyjną), to i tak zasadnie można formułować pytanie o to, kto jest odbiorcą tekstu literackiego, a także czy taki właśnie tekst można sensownie analizować bez wzięcia pod uwagę wspólnoty duchowej twórcy i odbiorcy tekstu.

Mówiąc o wspólnocie (np. myślenia, duchowej), sugerujemy zestaw pytań o fundamentalne problemy antropologiczne, a więc o to, czy właściwie jest pytanie o tę wspólnotę w badaniach naukowych i co ona dzisiaj znaczy? Jak mają się do siebie rozmaite strategie badawcze i związany z nimi stosunek do źródeł, do wyselekcjonowanego materiału? Czy preferowana powinna być konstrukcja, dekonstrukcja czy wierność badanemu źródłu? Co więcej, czy problem tej wspólnoty nieuchronnie musi prowadzić do określonego doświadczenia tekstu - w jakim zakresie i co dokładnie to doświadczenie oznacza? I wreszcie, na ile uzasadniony jest lub byłby powrót do pojęcia wspólnoty duchowej będącej centrum

11 Por. F. Znaniecki, op. cit., s. 279-280; M. Jahoda, P.F. Lazarsfeld, H. Zeisel, Bezrobotni Marienthalu, przeł. R. Marszałek, Warszawa [1933] 2007, s. 65-165. 
świata przeżywanego. To ostatnie pojęcie, jako że jest z różną częstotliwością używane we wszystkich naukach społecznych i humanistycznych, wydaje się bardzo przydatne do szukania tej wspólnoty w praktycznych kontekstach dokonywania zapisów autobiograficznych.

Drugi zestaw problemowych pytań dotyczy relacji intencji autora, treści źródła i nośnika w różnych formach dokumentów osobistych (nieliterackich, paraliterackich, literackich). Poziom ważności każdego z tych trzech elementów i skala zainteresowania nimi mogą być rozmaicie określane zarówno w różnych naukach, jak i paradygmatach badawczych. Prymat żadnej z części nie jest przecież oczywisty, a co ważniejsze, pytania i problemy, które formułujemy, nie zamykają się w pełni w żadnej traktowanej autonomicznie dziedzinie nauki.

Ostatni zestaw jest związany z charakterystyką warstw źródła literackiego. Dla niektórych badaczy ontologia tekstu literackiego stała się punktem wyjścia do ontologii źródła historycznego, a przejście dokonało się ze względu na cel badawczy, którym jest analiza świata przeżywanego. Być może właśnie wokół koncepcji Lebenswelt, jego elementów i warstw oraz jego struktury mogą ogniskować się wysiłki badaczy zajmujących się źródłami pisanymi i dokumentem osobistym w wybranych kontekstach, np. literackich, historycznych oraz społecznych. Takie kwestie, jak intencja, treść, nośnik stawiają nas wobec problemu przeżywania świata, wskazując zarazem cały wachlarz zróżnicowanych ujęć, które w rozmaity sposób przedstawiać mogą „subiektywność” intencji, „obiektywność” otaczającego świata rzeczy (nośnik).

Owe trzy zestawy uwrażliwiają czytelnika na interpretacje ukryte w sposobie pogrupowania tekstów przedstawicieli sześciu dyscyplin naukowych w trzy niejednokrotnie zależne od siebie obszary badawczych poszukiwań: „Kategorie dokumentu osobistego na przecięciu wywiadu i (auto)biografii” (5 artykułów), „Dokument osobisty w przykładowych podejściach warsztatowych” (4 artykuły) oraz „W kierunku doświadczenia, nie tylko literackiego” (5 artykułów).

\section{Kategorie dokumentu osobistego na przecięciu wywiadu i (auto)biografii}

Rozpoczynamy artykułem Elżbiety Zakrzewskiej-Manterys pt. Dokumenty osobiste $w$ doświadczeniach badawczych, albowiem zawiera on niezwykle ważne kwestie dla badaczy społecznych, którzy profesjonalnie zajmują się tekstami pisanymi, a także odnosi się do takich kategorii, jak m.in. wywiady biograficzne, dane urzędowe, podejście interpretatywne, psychologizm. W tekście prezentowana jest też diagnoza stanu konkretnych podejść socjologii do tekstów pisanych jako materiału empirycznego. Autorka przedstawia nie tylko dwa nurty w metodologii badań tekstów pisanych - dominujący (tzw. mainstreamowy) i konstruktywistyczny - lecz także współczesne dążenia do wyjścia z tych paradygmatów metodologicznych. Natomiast podkreślenie oczywistego miejsca twórczości 
Floriana Znanieckiego w tradycji badań humanistycznych zapowiada użycie jego koncepcji z różną mocą i natężeniu w kolejnych tekstach tomu. To podkreślenie jest tym bardziej ważne, że Znaniecki posługiwał się terminem „świat humanistyczny”, „z którego wyłaniają się systemy kulturalne” 12 , co odnosiło się do pojęcia świata przeżywanego we współczesnym jego rozumieniu.

Mateusz Gałkowski w tekście Narracja w kontekście pozyskiwania danych urzędowych bardzo ciekawie nawiązuje do zalet zastosowania w kontekście wywiadu danych narracyjnych. Płaszczyzną, na której je rozważa, jest ważny w procesie decyzyjnym urzędu miejskiego sposób przydziału lokalu socjalnego. Narracyjność, zdaniem autora, powinna odgrywać ważniejszą rolę w procesie zbierania danych urzędowych, albowiem dotychczas stosowane podejście, niejako ekonomiczno-ilościowe, służyło „wygodzie” liczenia faktów przede wszystkim samym urzędnikom.

Poprzez pojęcie narracyjności przechodzimy do artykułu Olgi Nowaczyk $\mathrm{Pa}$ miętniki żołnierzy uczestniczacych $w$ działaniach wojennych jako przykład materiałów uzupetniających wywiady biograficzne. Badaczka prowadzi przekonującą argumentację na rzecz tego, że pisane dokumenty osobiste są wolne od wpływu sytuacji badawczej oraz dają możliwość dokonania wglądu w refleksyjną świadomość i indywidualną sferę wiedzy piszącego. Szczególnie ważna jest kwestia etyczności badań, gdy tematyka poruszana przez badacza dotyczy doświadczeń wojennych.

Podobnym zagadnieniem, choć ujętym od innej strony, zajęła się Katarzyna Stańczak-Wiślicz w tekście Lektura nieporzadku - kilka przykładów narracji autobiograficznych $z$ okresu Zagłady. Opiera się on na analizie narracji autobiograficznych dziewcząt i młodych kobiet piszących w okresie Zagłady na terenie okupowanej Polski. Zastosowana do analizy kategoria „lektury nieporządku” ukazała sposób, w jaki autorki udokumentowały cierpienie wynikające z poczucia chaosu.

Problematyka sposobu doświadczania przez kobiety jest osią ostatniego w tej części tekstu Dlaczego kobiety nie mają swojej historii? „Wspomnienia” Aleksandry Pitsudskiej $i$ ich rola $w$ budowaniu legendy Józefa Piłsudskiego Marty Sikorskiej-Kowalskiej. Czerpiąc z filozofii i historiografii postmodernistycznej, mieści się on w nurcie badań feministycznych. Autorka podejmuje problem „przywrócenia historii kobiet" i jednocześnie konstatuje, że feministyczna krytyka literacka „znalazła się w ślepym zaułku”. Dochodzi do przekonania o niemożności badania podmiotowości kobiet poprzez analizę ich autobiografii. W tym sensie artykuł jest częścią większej całości i dużo szerszego zamysłu badawczego. Jednak właśnie konkretne, analizowane przez Sikorską-Kowalską źródło umożliwia sformułowanie mocnych tez m.in. o roli zapisu w ich życiu codziennym: „kobiety nie mają swojej historii bo zabrakło miejsca na tę historię w męskich narracjach oraz że na-

12 F. Znaniecki, Wstęp do socjologii, Warszawa 1988, s. 179. 
wet jeśli potrafiły myśleć i pisać, to spisały historię mężów, synów i braci. Uznały, że ich wkład do polityki, rozwoju społeczeństwa był tak mały, że nie warto o nim pisać". Z jednej strony artykuł jest wyrazem sceptycyzmu wynikającego z milczenia źródeł, z drugiej natomiast autorka, niejako wbrew źródłu, próbuje rekonstruować historię kobiet. Rodzi się więc pytanie wykraczające poza problem intencji, treści i nośnika, dotyczące możliwości analizy źródła przeciw niemu samemu, czyli jego dekonstrukcji.

\section{Dokument osobisty w przykładowych podejściach warsztatowych}

W tej części prezentujemy cztery teksty, które z różną mocą nawiązują do tradycji Floriana Znanieckiego, to znaczy badań na podstawie listów i pamiętników. Zaczynamy nieco prowokacyjnie wobec rozważań Znanieckiego, który na wielu stronach swoich dzieł polemizował z podejściem psychologizującym. Magdalena Żurko w artykule pt. Wybrane psychologiczne metody jakościowe stosowane $w$ badaniach nad tekstem pisanym przedstawia nurt interpretatywny w psychologii i dokonuje konkretyzacji empirycznej tego podejścia, analizując metodą McAdamsa jeden z pamiętników nadesłanych na konkurs ogłoszony przez Instytut Socjologii Uniwersytetu Wrocławskiego. W związku z celami tomu podkreślić należy dwa wątki tego tekstu. Po pierwsze - wpływ socjologii na omawiany przez autorkę nurt psychologii, a po drugie - związek owego nurtu z tzw. żywą historią, dla której fundamentalną wartość mają właśnie dokumenty osobiste.

Elementy zatopienia w historii odnajdujemy w artykule Anny Dolińskiej pt. Bliskie relacje na odległość $w$ migranckich rodzinach chłopskich na poczatku XX wieku. Analiza serii listów Stelmachów. Badaczka zwróciła w nim uwagę na relacyjny charakter korespondencji i budowanie dzięki niej poczucia bliskości. Odwołując się do paradygmatu transnarodowości i współczesnych zjawisk towarzyszących migracjom rodzin, zaprezentowała, jak rodzina galicyjskich chłopów-rolników starała się wspólnie doświadczać przestrzeni i uczuć ponad granicami w czasach sprzed rewolucji technologicznej.

Omawianą część tomu kończą analizy fragmentów Pamiętnika Jana Chryzostoma Paska będące wynikiem bogatych doświadczeń warsztatów metodologicznych. Jerzy Żurko w artykule pt. Struktury kulturowe w „Pamiętnikach” Jana Chryzostoma Paska. Doświadczenia warsztatowe oraz Marcin Stabrowski w Analizie kulturoznawczej dwóch akapitów z „Pamiętników” Jana Chryzostoma Paska postawili sobie za cel dotarcie do struktur kulturowych zawartych w dziele Paska i zarazem zbudowanie podwalin pod nowe rozumienie historii kultury jako historii systemów wartości. Obydwa teksty biorą pod uwagę założenia fenomenologii, teorii kultury Stanisława Pietraszki oraz założenie o obiektywności świata wartości, który badacz tylko odtwarza. Analiza dokonana w artykule Żurki jest bliska podejściu systemowo-strukturalnemu, natomiast ta dokonana przez Stabrowskiego - 
podejściu hermeneutycznemu. Przez porównanie obu analiz czytelnik uzyskuje obraz struktur kulturowych „uwspólniony”, jakby zobiektywizowany. Oba teksty uwzględniają to, że Pamiętniki Paska są wyrazem struktur kulturowych charakterystycznych dla „braci szlacheckiej” jako grupy uczestników kultury XVII wieku w Polsce.

Zbliżone do siebie obszary analiz Stabrowskiego i Żurki skupiają się na badaniu staropolskich pamiętników (przede wszystkim J.Ch. Paska) w ten sposób, aby (zgodnie z zaleceniem Znanieckiego) pokazać, jak „na ogólnym podłożu świata humanistycznego [...] wyłaniają się systemy kulturalne"13, a w tym wypad$\mathrm{ku}$ - jak narracja przedstawicieli „braci szlacheckiej” przekazuje obraz systemu kulturowego, którego byli oni twórcami. Podobny cel badań przyświeca Dolińskiej w odniesieniu do listów Stelmachów. Omawiana przez nią relacja bliskości i intymności jest zarazem tworzeniem świata przeżyć i próbą ocalenia, podtrzymania wspólnoty tych przeżyć. Żurko psychologicznie realizuje ten cel w odniesieniu do anonimowego pamiętnika konkursowego, którego autor ukazuje siebie jako ofiarę przemian systemowych w okresie transformacji. Świat jego przeżyć był w końcu dla części społeczeństwa polskiego wspólny, co do dziś tworzy realne zaplecze wspólnot kulturowych w Polsce.

\section{W kierunku doświadczenia, nie tylko literackiego}

Założenia fenomenologiczne ujawniły się już w sposób pełny w artykule Marka Magdziaka i Marcina Stabrowskiego pt. Ontologiczne aspekty interpretacji dokumentów osobistych. Przyjmując schemat postępowania analitycznego zaczerpnięty z dzieła Romana Ingardena $O$ dziele literackim oraz wykorzystując założenia fenomenologii Edmunda Husserla i Maxa Schelera, podjęli się analizy Pamiętników Ignacego Daszyńskiego. Badacze omówili siedem warstw źródła historycznego, które są kluczowe dla pełnego poznania świata przeżywanego, wyrażonego w źródle. Doszli do wniosku, że zaproponowana przez nich metodologia pozwala na uchwycenie ważnych elementów świata przeżywanego, lecz warunkiem jest to, że analiza tego typu źródła musi uwzględniać reguły i konteksty całości rekonstruowanej hierarchii wartości, a nie współczesne badaczowi przekonania. Wyróżnione warstwy ujawniają transdyscyplinarne cechy badania, pozwalając na zachowanie tożsamości badawczej, z jednoczesnym zintensyfikowaniem współpracy pomiędzy naukowcami wywodzącymi się z różnych dziedzin, albowiem o ile każda $\mathrm{z}$ warstw pozwala na poznanie świata przeżywanego, o tyle nie każda dyscyplina równie skutecznie może daną warstwę uchwycić i analitycznie opisać. Zastosowane przez nich podejście jest warte wnikliwej analizy z punktu widzenia

13 Ibidem. 
sposobu dotarcia do świata przeżywanego przy uwzględnieniu formuły „systemów kulturalnych" Znanieckiego.

Odniesieniami do Maxa Schelera przechodzimy do tekstu Łukasza Rozwadowskiego na temat Lektury kulturoznawczej „Peregrynacji po Europie” Jakuba Sobieskiego. Badacz stara się w nim przedstawić metodę redukcji świata przeżyć do sfery wartości, koncentrując się na momentach, których istotą są sposoby odnoszenia się Sobieskiego do Boga, człowieka i świata w trakcie doświadczania podróży.

Tym właśnie motywem, choć rozumianym bardziej etnograficznie, przechodzimy do tekstu Marcina Dębickiego pt. $Z$ idiograficzności zmagań $z$ twórczościa Andrzeja Stasiuka. Rozważania na temat prozy Stasiuka są w nim zakorzenione w metodologii wywodzącej się z antropologii w nurcie refleksyjnym. Autor artykułu widzi siebie jako „podróżnika, badacza terenowego”, dla którego ramy teoretyczne i metodologiczne są równie niezbędne jak własne doświadczenie podróżnicze. Mimo że takie podejście jest kontrowersyjne w socjologii literatury, to jednak zdaniem Dębickiego jego źródeł można dopatrzeć się u samego Znanieckiego. Wykraczając zaś poza treść artykułu, warto podkreślić, że pytanie o doświadczenie badacza i badanego, szczególnie w kontekście tekstu pisanego, zajmuje coraz ważniejsze miejsce w dziedzinach nauk społecznych i humanistycznych.

Ostatnie dwa artykuły dotyczą tekstów literackich, a przynajmniej takich, w których literackość jest nie do pominięcia, chociaż może być dyskutowalna. Pozornie zatem badanie literackości tekstu literackiego jest badaniem konkretnej, chociaż wielowarstwowej struktury w tekście (literackości właśnie), albowiem metodologiczne zamierzenia autorów tych artykułów są znacznie szersze i dotyczą rekonstrukcji świata przeżyć. Berenika Dyczek w artykule pt. Relacja między czynnościami i dążnościami ludzkimi a wartościami, według Floriana Znanieckiego, czyli jak badać teksty kultury ukazuje miejsce wartości w uniwersum świata człowieka według Znanieckiego. Badaczka pokazała m.in., w jaki sposób Znaniecki odrzucał różne współczesne mu podejścia do wartości (w tym swoje wcześniejsze) i w ten sposób zbliżał się do tego, które zaproponował w swoich już późnych dziełach Jurij Łotman. Te podstawowe ustalenia dotyczące koncepcji Znanieckiego i Łotmana wzbogacone zostały odniesieniem do analiz praktyki literackiej Dzienników Witolda Gombrowicza. Kontrowersyjnym, i przez to ciekawym, zabiegiem jest umieszczenie Gombrowicza jednocześnie w roli autora analizowanego źródła oraz partnera w dyskusji nad nauką i współczesnością.

Tę część tomu zamyka artykuł Leopold Tyrmand. Dziennik pisarza: autokreacja i powieść Hanny Jaxy-Rożen. Autorka próbuje dociec, czym w istocie jest dziennik jako tekst literacki. Posługując się podejściem i metodami literaturoznawczy$\mathrm{mi}$, snuje rozważania nad charakterystyką gatunkową tego tekstu. Stawia pytanie o literackość tekstu (czy też jego paraliterackość), przedstawiając w odniesieniu do dokumentów osobistych bogaty kontekst typologii źródeł literackich i paraliterackich. Przeprowadzona przez nią analiza źródła niejako mimochodem poru- 
sza ważne problemy, które nie zamykają się li tylko w obszarze badań literaturoznawczych (wspomnianym wcześniej problemie formy), lecz przede wszystkim intencji. Nie sposób uniknąć tych pytań, gdy czytamy, że „największym osiągnięciem Leopolda Tyrmanda jest Leopold Tyrmand".

Prezentowany tom „Forum Socjologicznego” kończy zestaw recenzji i sprawozdań. Antoni Płoszczyniec (Rzeczywistość a zapis, czyli co filozof może dowiedzieć się od socjologa?) oraz Grażyna Woroniecka (Wokót tekstów, czyli o czym mówi pismo) krytycznie zajęli się publikacją, która podobnie do prezentowanego tomu porusza transdyscyplinarne kwestie dokumentów osobistych, zapisu autobiograficznego, (nie)fikcji literackiej - Rzeczywistość i zapis. Problemy badania tekstów w naukach społecznych i humanistycznych, red. W. Doliński, J. Żurko, K. Grzeskiewicz-Radulska, S. Męcfal, Łódź 2016, ss. 250. Agata Krasowska (Przełamane herstorie) zrecenzowała książkę Marty Abramowicz Zakonnice odchodza po cichu (Wydawnictwo Krytyki Politycznej, Warszawa 2016). Hanna Jaxa-Rożen (Kultura i aktywizacja do zmiany (społecznej)) zajęła się omówieniem książki Jacka Schindlera Kulturowe uwarunkowania procesów aktywizacyjnych (Dolnośląskie Wydawnictwo Edukacyjne, Wrocław 2014), a Julita Makaro zrecenzowała książkę Dawida Błaszczaka (2016) Kapitał społeczny w sieci wspótpracy transgranicznej Białej Podlaskiej.

W sprawozdaniu Marcin Dębicki i Kamilla Dolińska opisali nową inicjatywę wrocławskich socjologów, mianowicie Sekcję Socjologii Etniczności Polskiego Towarzystwa Socjologicznego (PTS). Adam Mrozowicki, Elżbieta Kolasińska, Joanna Róg-Ilnicka zaprezentowali problemy poszukiwania tożsamości polskiej socjologii pracy w XXI wieku w ramach działania Sekcji Socjologii Pracy PTS. Julita Makaro przedstawiła wybrane elementy popularyzatorskiej działalności wrocławskiego oddziału PTS (Wrocławscy socjologowie poza murami uczelni), a Jan Maciejewski i Daria Hofman - sprawozdanie z XXVII Międzynarodowej Konferencji Naukowej pt. „Zadania jednostek administracyjnych samorządu terytorialnego $\mathrm{z}$ wykorzystaniem potencjału grup dyspozycyjnych w przeciwdziałaniu zagrożeń bezpieczeństwa publicznego", która odbyła się we Wrocławiu w maju 2016 roku. Tę część tomu zamyka tekst o polskich pograniczach w procesie przemian, który napisały Elżbieta Opiłowska i Mariya Kamenskaya.

Wojciech Doliński, Marcin Stabrowski, Jerzy Żurko

\section{Bibliografia}

Baszczak B., Paula Ricoeura hermeneutyka tekstu, „Fenomenologia” 2007, nr 5, s. 127-149.

Czekalska R., „Pisz mi o wszystkim dokładnie...” - rzeczywistości kulturowe w listach malarzy z kręgu Bombay Progressive Artists' Group, „Societas/Communitas” 2015, nr 1-2 (19-20), s. 237-254.

Doliński W., Zapisy autobiograficzne - od doświadczenia do map interpretatorów, „Przegląd Socjologii Jakościowej" 13, 2017, nr 3 (w druku). 
Doliński W., Żurko J., Wybrane problemy statusu poznawczego tekstów pisanych - wprowadzenie, [w:] Rzeczywistość i zapis. Problemy badania tekstów w naukach społecznych i humanistycznych, red. W. Doliński, J. Żurko, K. Grzeszkiewicz-Radulska, S. Męcfal, Łódź 2016, s. 7-21.

Dybel P., Granice rozumienia i interpretacji. O hermeneutyce Hansa-Georga Gadamera, Kraków 2004.

Gadamer H.G, Prawda i metoda. Zarys hermeneutyki filozoficznej, przeł. B. Baran, Warszawa 2004.

Jahoda M., Lazarsfeld P.F., Zeisel H., Bezrobotni Marienthalu, przeł. R. Marszałek, Warszawa [1933] 2007.

Lutyńska K., Męcfal S., „Przegląd Socjologiczny” 64, 2015, nr 4.

Metoda biograficzna w socjologii, red. K. Kaźmierska, Kraków 2012.

Ricoeur P., Język, tekst, interpretacja, przeł. P. Graff, K. Rosner, Warszawa 1989.

Rzeczywistość i zapis: problemy badania tekstów w naukach społecznych i humanistycznych, red. W. Doliński et al., Łódź 2016.

Ziemiańska-Sapija D., Semiotyka szkoły tartuskiej jako nauka o kulturze, Warszawa 1987.

Znaniecki F., Metoda socjologii, przeł. E. Hałas, Warszawa [1934] 2007.

Znaniecki F., Wstęp do socjologii, Warszawa 1988.

Żyłko B., Semiotyka kultury. Szkoła tartusko-moskiewska, Gdańsk 2009. 